\title{
The Effect of Explicit Instruction of Meta Cognitive Learning Strategies on Promoting Iranian Intermediate Language Learners' Writing Skill
}

\author{
Keramat Ahmadi \\ Islamic Azad University, Shahreza Branch, Iran \\ Email: Keramat.ahmadi@yahoo.com \\ Saeed Ketabi \\ Islamic Azad University, Shahreza Branch, Iran \\ Email: S.Ketabi@yahoo.com \\ Mitra Rabiee \\ Islamic Azad University, Shahreza Branch, Iran \\ Email: Mitra_Rabiee@yahoo.com
}

\begin{abstract}
The present study was an attempted to investigate the effect of explicit instruction of meta-cognitive learning strategies on promoting intermediate language learners' writing skill. To achieve this purpose, an Oxford Placement test (Allen, 2004) was administered to language learners in English language institution and ultimately 24 intermediate language learners were selected and randomly assigned to an experimental group and a control group. Both groups worked on the same writing tasks and activities. The subjects in the experimental group were also instructed in the use of meta-cognitive language learning strategies following O'Malley (1985) while the subjects in the control group received some placebo treatment for a whole term. The results of the posttest showed that explicit instruction of meta-cognitive learning strategies for intermediate language learners proved effective. One reason may be that language learners at the intermediate level draw on these strategies in a conscious fashion and they need to develop a conscious awareness of the meta-cognitive learning strategies.
\end{abstract}

Index Terms_-proficiency levels, EFL learners, writing skill, meta-cognitive strategies, explicit instruction

\section{INTRODUCTION}

Language learning strategies are referred to as the choices which language learners make while they are involved in learning or utilizing a second language (Cook, 2001). Brown (1994) states that "as the knowledge of second language acquisition increased noticeably during the 1970s, teachers and researchers realized that no single research finding and no single method of language teaching would commence an era of utopia of absolute, predictable success in teaching a second language"(pp. 145-152). The methods or techniques of teaching notwithstanding, certain learners seemed to be successful. The importance of individual variation in language learning was spotlighted, and certain learners appeared to be endowed with abilities to develop in a successful way, others not possessing those abilities.

Grounded upon the above-mentioned proposition, traditional methodologies were considered dreary and poor in value for the language learners because they did not take into account individual learning differences. The 1970s henceforth witnessed the drastic changes in language pedagogy throughout the world. This period could be deemed a great triumph for language teaching and learning since some pre-eminent amendments in the era of language pedagogy occurred. One of the changes was the application of language learning strategies. Chamot and Kupper (1989) studied the use of learning strategies by foreign language students and their teachers for three years. Their study revealed that students of all ability levels used language learning strategies. What discriminated effective learners from less effective learners were the range and the way in which strategies were drawn on. In their study, effective language learners made use of strategies more often, more appropriately, along with greater variety, and in ways that helped them complete the task successfully.

\section{THE PURPOSE OF THE STUDY}

Language learners run into difficulty comprehending writing tasks and activities when they start to write without being prepared in advance by their teacher. Or they may not know what part of the writing task they should focus their 
attention on. These are some predicaments of language classes wherein writing activities play a significant role. To contribute to language learners' writing skill, application of language learning strategies, meta-cognitive ones in particular, is required of the language learners.

A number of studies have been carried out on learning strategies and language learning but they did not thoroughly deal with the explicit instruction of meta-cognitive learning strategies and the writing skill at the intermediate level (Ehrman and Oxford, 1989; Green and Oxford, 1995; Liu, 2004). Therefore, they are considered inconclusive in their results for intermediate language learners.

To this aim, the researcher capitalized on the explicit instruction of meta-cognitive learning strategies for intermediate language learners to enhance their writing skill. The study focused only on intermediate level due to the paucity of research at this level.

\section{RESEARCH QUESTIONS}

In order to draw up the boundaries of research, this study intended to pursue the following questions:

1. Is there any significant relationship between meta-cognitive learning strategy use and EFL writing achievement?

2. Does explicit instruction of meta-cognitive learning strategies have any significant effect on promoting Persian intermediate language learners writing skill?

\section{RESEARCH HYPOTHESES}

Following the above questions are the hypotheses upon which the present research has been conducted:

H01: there is no significant relation ship between meta-cognitive learning strategy use and EFL writing achievement.

H02: Explicit instruction of meta-cognitive language learning strategies doesn't promote Persian intermediate language learners' writing skills.

\section{WRITING SKILL AND LEARNING STRATEGy USE}

Writing, like speaking, is a productive skill. Writing requires deeper knowledge of the grammar system than receptive skills and perhaps even much deeper than speaking .obviously, writing to communicate can be possibly only when students have sufficient control of writing system. Writing is a cognitive function that requires learners to become involved in intellectual tasks. Well-developed Meta cognitive awareness strategies in writing help students to create meaningful learning goals that can be monitored and evaluated. Meta cognitive skills in writing require students to think effectively about their own thinking in relation to a given writing task.

Chastain (1988) states that "a conversation class cannot merely be comprised of speaking activities" (pp. 36-41). A conversation class is to entail writing practice as well. Chastain's point crystallizes the inclusion of all four language skills in a language class if the class wishes to appear realistic and productive

In accord with the statements given above, one can conclude that teaching of the writing skill should be accompanied with modern views of language pedagogy. For instance, language learning strategies would be of help to learners if employed in language learning, especially in the writing skill, and language teachers should attempt to incorporate learning strategies into the teaching of the writing skill. Also, to expedite their learning in the writing skill, language learners could make use of learning strategies.

\section{A. Meta-cognition and Meta-cognitive Strategies}

Psychologically speaking, meta-cognition is referred to as knowledge of the mental processes which individuals benefit from in their learning. To provide the history of the term, it should be said that meta-cognition correlates with Flavell (1979). Flavell argues that meta-cognition encompasses meta-cognitive knowledge and meta-cognitive experiences or regulation. In his definition, Flavell says that meta-cognitive knowledge makes a reference to acquired knowledge respecting cognitive processes: the type of knowledge that could be made use of to supervise cognitive processes (Flavell, 1979). Borkowski, Carr, and Pressley (1987) and Sternberg (1984, 1986) contend that metacognition could enable learners to succeed in their learning processes. They also claim meta-cognition is associated with intelligence.

Livingston (1997) states that meta-cognition refers to supervisory thinking which embodies active control over the cognitive processes engaged in learning process. She argues that activities such as planning how to approach a given learning task, monitoring comprehension, and evaluating progress toward the completion of a task are some metacognitive strategies in nature.

Richards and Schmidt (2002, pp. 328-329) state that meta-cognition "is knowledge of the mental processes which are involved in different kinds of learning. Learners are said to be capable of becoming aware of their own mental processes". This includes recognizing which kinds of learning tasks cause difficulty, which approaches to remembering information work better than others, and how to solve different kinds of problems. Meta-cognitive knowledge is thought to influence the kinds of learning strategies learners choose.

Anderson (2002) states that meta-cognition can be defined simply as thinking about thinking. Learners who are metacognitively aware know what to do when they do not know what to do; that is, they have strategies for finding out or 
figuring out what they need to do. The use of meta-cognitive strategies ignites one's thinking and can lead to more profound learning and improved performance, especially among learners who are struggling. Understanding and controlling cognitive processes may be one of the most essential skills that classroom teachers can help second language learners develop. It is important that they teach their students meta-cognitive skills in addition to cognitive skills.

Flavell (1979) states that meta-cognition is the process of thinking about thinking. He describes meta-cognition "as referring to one's knowledge regarding one's own cognitive processes or anything which is related to them, that is, the learning-related properties of information or data. Meta-cognitive strategies are the learning strategies which have executive roles in learning" (pp. 152-158). Plans for how to learn something, thinking about learning processes as they occur, monitoring one's production or comprehension, and evaluating what has been learned after an activity is completed are termed meta-cognitive strategies (Brown, 1994). Nunan(1999) declares that meta-cognitive strategies are learning strategies that encourage learners to focus on the mental processes underlying their learning.

Language learners either consciously or unconsciously utilize techniques to peak their learning. For instance, some may have difficulty memorizing new words in a conversation, so they make attempts to, say, write the words on one side of a card and on the other side, the meaning of the word is written. Others may find it hard to work out the grammatical rules. These are some strategies used to better increase the power of learning. Memorization of the new words and learning the present continuous tense are cognitive processes, the transcending knowledge supervising these processes is meta-cognition, and those strategies used to enhance learning are called meta-cognitive strategies.

\section{B. Strategy Training}

Bachman (2002) states that deliberate instruction of cognitive and meta-cognitive strategies increases most learners' ability to learn. He also claims that learners with conspicuous learning problems can improve their learning through strategy learning. Studies have demonstrated that when struggling learners are instructed in learning strategies and afforded considerable encouragement, feedback, and opportunities to apply them, learners better process information and they improve their ability to learn. Bachman alleges that some learners face up to difficulty when they want to embed strategy use in their learning schema. In this case, he adds, there should be differentiation of strategy teaching, with some learners requiring more scaffolding and individualized, intensive instruction than others (pp.142-151).

O'Malley's (1987) study regarding the effect of different types of strategy training, meta-cognitive, cognitive, and socio-affective, on different language skills revealed a significant effect on the speaking skill, but the training of these strategies did not impact on the listening skill.

MacIntyre and Noels(1996) declare that teachers can motivate their students by showing them how and when to make use of learning strategies to improve their learning process. They also say that teachers are supposed to show their students how efficacious strategy use can be through successful experiences(pp. 373-386).

Oxford's research (1989) on strategy instruction reveals that some studies on L2 strategy training have not led to successful or conclusive results. She states that some strategy training has been efficacious in various skill areas but has appeared ineffective in other skill areas, even within the same study (pp. 237-245).

Eslami Rasekh and Ranjbary (2003, p. 1) claim that learners should be taught about the learning strategies and about when to make use of them as well. Learners need to be instructed in how to select the most appropriate strategy in learning situations. The result of their study revealed that explicit meta-cognitive strategy training had a positive effect on the vocabulary learning of EFL students.

Respecting the teachers who teach learning strategies, Oxford, Crookall, Cohen, Lavine, Nyikos, and Sutter(1990) claim that teachers who use strategy training often become enthusiastic about their roles as facilitators of classroom learning. Strategy training makes them more learner oriented and more aware of their students' needs. Teachers also begin to scrutinize how their teaching techniques relate (or fail to relate) to their students' learning strategies and sometimes teachers choose to alter their instructional patterns as a result of such scrutiny (Oxford, Crookall, Cohen, Lavine, Nyikos, and Sutter, 1990, p. 210).

\section{METHODOLOGY}

\section{A. Participants}

To select the homogeneous subjects, the researcher administered a sample Oxford placement test to 40 students who enrolled in language institute (Talash Language institute) in Kazeroon, Based on their scores, 24 students were selected as intermediate English language learners. The selected subjects were all male and randomly divided into two groups of 12, one was control group and the other one was experimental group. The experimental group was instructed to employ metacognitive learning strategies to promote their writing skill during the whole term, while the control group did not receive any special treatment. Having administered the necessary statistical calculations, the researcher selected 24 students who had scored between 52 and 67 out of 100 as intermediate language learners. The research took a whole term.

\section{B. Instruments}

The material used in this study comprised a) an Oxford placement test (OPT, 1992) with 100 multiple choice items on various grammatical points to select intermediate language learners. b) A pre test of writing in essay format for both 
the experimental and control groups to assess their initial knowledge writing skill and use of Meta cognitive learning strategies.

c) The third instrument was the explicit instruction of meta-cognitive strategies for writing skill. Explicit instructions were provided for the experimental group throughout the whole semester. The meta-cognitive strategies were selected from O'Malley et al. (1985b).

d) The forth instrument was a post test to measure the writing performance of participants in the experimental and control groups after explicit instruction of metacognitive learning strategies were given. This writing test was in essay format with around 100 words.

\section{Procedure}

A sample language learning proficiency test (Oxford placement test, Allen, 2004) was administered to select intermediate Iranian EFL learners in Talash language institute in Kazeroun,Iran. Then the pretest of a writing performance was given to all participants. In this test, a topic was given to write about in an essay format. Each participant was asked to write a paragraph of no less than ten lines. Then, the explicit instruction on the use of metacognitive learning strategies for the experimental group was structured in 30 minute for whole semester. This strategy composed of five stages based on CALLA model (Cognitive Academic Language Learning Approach) by Chamot and O'Malley (1994) and they were as follows:

1. Preparation: The purpose of this phase was to help students identify the strategies they are already using and to develop their meta-cognitive awareness of the relationship between their own mental processes and effective learning. In this step the teacher explained the importance of meta-cognitive learning strategies.

2. Presentation: The subjects were provided with meta-cognitive learning strategies after they were thoroughly acquainted with their nature. They were taught on how they could make optimal use of these strategies.

3. Practice: At this stage, the subjects used some writing tasks and activities and they were asked to perform them by incorporating the meta-cognitive learning strategies.

4. Evaluation: At this stage, the subjects were instructed to evaluate their progress in their writing skill.

5. Expansion: At this stage, the subjects were encouraged to apply the meta-cognitive learning strategies for appropriate writing tasks and activities. They were told that they could make use of some other meta-cognitive learning strategies which were suitable to their writing skills. Finally, the writing ability test (writing 100 word informative essays) was given after implicit instruction of Meta cognitive strategy to assessed students on writing achievement after this instruction. Then the participant's scores on the pretest and post test were compared to find the possible degree of success on writing performance.

\section{DATA ANALYSIS}

Statistical analysis of $\mathrm{t}$ test was used to test possible differences between the two groups at the beginning and the end of the study. In order to establish the homogeneity of the two groups in terms of writing knowledge, an independent sample t-test was carried out to examine the differences between the performance of the two groups on the writing test before the meta-cognitive strategy training.

TABLE1:

DESCRIPTIVE STATISTICS PERTAINING TO THE PRETEST

\begin{tabular}{|l|l|l|l|l|}
\hline DESCRIPTIVE STATISTICS PERTAINING TO THE PRETEST \\
\hline Groups & $\mathrm{N}$ & Mean & Std. Deviation & Std. Error of Mean \\
\hline control & 12 & 13,7500 & 2,00567 &, 57899 \\
\hline experimental & 12 & 13,1667 & 1,74946 &, 50503 \\
\hline
\end{tabular}

As can be seen in table 4.1, there is not any significant difference between the mean scores of the subjects in the control group (mean $=13.7500$ ) and the subjects in the experimental group(mean=13.1667). In simple words, the two groups were homogenous in terms of writing knowledge at the beginning of the training.

Both groups took part in a posttest after completing the training in which only experimental group received meta cognitive strategy training. The results of the writing test in the two groups were compared by using independent samples t-test statistical procedure.

TABLE2:

DESCRIPTIVE STATISTICS PERTAINING TO THE POSTTEST

\begin{tabular}{|l|l|l|l|l|}
\hline Groups & N & Mean & Std. Deviation & Std. Error of Mean \\
\hline control & 12 & 14,4167 & 2,06522 &, 59618 \\
\hline experimental & 12 & 14,5000 & 1,50756 &, 43519 \\
\hline
\end{tabular}

As shown in table 4.2 the mean scores of the experimental group (Mean=14.4167) are significantly different from the control group (Mean=145000). Table4.2 clearly shows that explicit instruction has impacted on experimental group writing ability in post test, but it had no effect on control group's writing ability before and after explicit instruction of metacignitive learning strategies.

Also, an independent sample t-test was carried out to examine the differences between the performance of the experimental groups in pre test and post test on the writing test. 
TABLE 3:

PAIRED SAMPLES T TEST OF EXPERIMENTAL GROUPS

\begin{tabular}{|cl|l|l|l|l|l|}
\hline groups & Mean & N & Std. Deviation & Std. Error Mean & Sig. (2_tailed) \\
\hline Pair 1 & $\begin{array}{l}\text { pre_test experimental } \\
\text { post_test } \\
\text { experimental }\end{array}$ & 13,1667 & 12 & 1,74946 &, 50503 \\
& 14,5000 & 12 & 1,50756 &, 43519 \\
\end{tabular}

The results indicate that there is a significant difference ( $\mathrm{t}$-test $=0.006 \mathrm{p}>.05$ ) between the mean scores of the subjects in the experimental groups in the pretest and post test. as shown in table4.3 we can clearly seen that the mean score in pre test(13.1667) has improved to(14.5000)in post test. This clearly shows that explicit instruction has impacted the on experimental groups writing ability in post test.

TABLE 4:

PAIRED SAMPLES T TEST OF CONTROL GROUPS

\begin{tabular}{|ll|l|l|l|l|l|}
\hline groups & Mean & N & Std. Deviation & Std. Error Mean & Sig. (2_tailed) \\
\hline Pair 1 & $\begin{array}{l}\text { pre_test } \\
\text { control } \\
\begin{array}{l}\text { post_test } \\
\text { control }\end{array}\end{array}$ & 13,7500 & 12 & 2,00567 &, 57899 &, 59618 \\
.013
\end{tabular}

And finally, an independent sample t-test was carried out to examine the differences between the performance of the control groups in pre test (mean=13.7500) and post test $($ mean=14.4167) on the writing test. The result in (table 4.4) indicated that there is not significant difference (t-test $=0.013 \mathrm{p}>.05$ ) between the mean scores of the subjects in the control group in pretest and post test. As table4.4 shows the mean score in pre test(13.7500) has little improved to(14.4167).This clearly shows that explicit instruction has not impacted on control groups writing ability before and after explicit instruction(Table 2).

As shown, the experimental group outperformed the control group in the post test. Thus, the explicit metacognitive strategy training seemed to have contributed to the improvement of students' writing skill. Therefore, the null hypothesis was not sustained which alleged that explicit instruction on the use of meta-cognitive learning strategies did not influence the writing skill when language learners wanted to regulate and self-direct their learning process. In other words, the t-value revealed that the two groups performed not equally on the posttest which was indicative of the fact that meta-cognitive strategy instruction afford the participants in the experimental group any privilege and as such had effect on promoting the writing skill.

\section{DISCUSSION}

This section discusses the results of the research by direct reference to the questions raised in the study.

Question One: Is there any significant relationship between meta-cognitive learning strategy use and EFL writing achievement?

Preceding studies have shown that meta-cognitive learning strategies are the strategies which differentiate between effective and ineffective learners (e.g. Anderson, 2002). Taking into account the results of the studies carried out in this regard, one could state that meta-cognitive learning strategies are paramount in language learning in general and in improving the writing skill in particular. O'Malley and Chamot's (1990) study manifested that meta-cognitive learning strategies improved most EFL students' speaking ability. As for the writing skill, they remarked that these strategies had positive effect on some writing tasks.

However, the results of the present study revealed that explicit instruction has been rendered effective to intermediate language learners. That is to say, intermediate language learners use these strategies consciously in their writing skill. So there is positive relationship between meta-cognitive strategy and EFL writing achievement.

Question Two: Does explicit instruction of meta-cognitive learning strategies have any significant effect on promoting Persian intermediate language learners writing skill?

The present study shows that intermediate language learners are aware of meta-cognitive learning strategies and utilize them consciously. This is because instruction could bring a change in the experimental group. This is in line with the suggestion by O'Malley and Chamot (1990) that intermediate language learners in general employ more metacognitive learning strategies. Therefore, instructing intermediate language learners in these types of strategies to promote their writing ability would be effective(Tables 2 and 3 ).

\section{CONCLUSIONS}

This study began with the assumption that teaching meta-cognitive learning strategies could enhance the intermediate language learners' writing skill ability. The instruction lasted for a whole semester. During this time, the teacher (researcher) employed meta-cognitive learning strategies and taught the subjects in the experimental group how to use them in their writing skill. The participants in the control group, on the other hand, did not receive any instruction on the use of these strategies during their writing skill practice. After the posttest, the results indicated that the instruction 
of meta-cognitive learning strategies affect the intermediate language learners' writing skill. That is, the writing ability of the experimental group who had made use of meta-cognitive learning strategies surpasses that of the control group.

\section{REFERENCES}

[1] Anderson, N. (2002). Using telescopes, microscopes, and kaleidoscopes to put metacognition into perspective. TESOL Matters, $12(4), 68-72$.

[2] Anderson, N. (2002). The role of metacognition in second language teaching and learning. Eric Digest, No. Edo-FL-01-10.

[3] Bachman, P. (2002). Strategy instruction. ERIC Identifier, No. ED 474302.

[4] Bialystok, E. (1978). A theoretical model of second language learning. Language Learning, 28, 69-83.

[5] Borkowski, J., Carr, M., \& Pressley, M. (1987). Spontaneous strategy use: Perspectives from metacognitive theory. Intelligence, 11, 61-75.

[6] Brown, H. D. (1994). Principles of language learning and teaching. New York: Prentice Hall Regents.

[7] Celce-Murcia, M. (Ed). (2001). Teaching English as a second or foreign language. Heinle and Heinle.

[8] Chamot, A. U. \& Kupper, L. (1989). Learning strategies in foreign language instruction. Foreign Language Annuals, $22,13-24$.

[9] Chamot, A. U., \& O'Malley, J. M. (1994). Learning strategies in second language acquisition. Cambridge: Cambridge University Press.

[10] Chamot, A. U. (2004). Issues in language learning strategy research and teaching. Electronic Journal of Foreign Language Teaching, 1 (1), 14-26.

[11] Chastain, K. (1988). Developing second-language skills: Theory and practice. Orlando: Harcourt Brace Jovanovich.

[12] Cohen, A. D., \& Aphek, E. (1980). Retention of second language vocabulary over time: Investigating the role on mnemonic associations. System, 8, 221-235.

[13] Cohen, A. D. (1998). Strategies in learning and using a second language. New York: Addison Wesley Longman Inc.

[14] Cook, V. (2001). Second language learning and language teaching. London: Arnold Publishers.

[15] Ehrman, M. \& Oxford, R. (1989). Adults' language learning strategies in an intensive foreign language program in the United States. The Modern Language Journal, 74, 311-326.

[16] Eslami Rasekh, Z. \& Ranjbary, R. (2003). Metacognitive strategy training for vocabulary learning. TESL-EJ, 7 (2).

[17] Flavell, J. (1979). Metacognition and cognitive monitoring: A new area of cognitive developmental inquiry. American Psychologist, 34, 906-911.

[18] Green, J. M. \& Oxford, R. (1995). A closer look at learning strategies, L2 proficiency, and gender. TESOL Quarterly, 29 (2), 261-297.

[19] Kaylani, C. (1996). The influence of gender and motivation on EFL learning strategy use in Jordan. In: Liu, D. (2004). EFL proficiency, gender, and language learning strategy use among a group of Chinese technological institute English majors. Arecls E-Journal, 1, 47-59.

[20] Krashen, S., (1982). Principles and practice in Second language Acquisition. Oxford: Pergamon.

[21] Larsen-Freeman, D. (2000). Techniques and principles in language teaching. Oxford: Oxford University Press.

[22] Livingston, J. A. (1997). Metacognition: An Overview. Retrieved August 11, 2006 from the World Wide Web: http://www.gse.buffalo.edu/fas/shuell/cep564/Metacog.htm

[23] MacIntyre, P. D., \& Noels, K. A. (1996). Using social psychological variables to predict the use of language learning strategies. Foreign Language Annals, 29, 373-386.

[24] McGroarty, M. (1987). Patterns of persistent second language learners: Elementary Spanish. Paper presented at TESOL Annual Meeting, 1987.

[25] Nunan, D. (1997). Does learner strategy training make a difference? RELC Journal, December, 1997.

[26] Nunan, D. (1999). Second language teaching and learning. Boston, Massachusetts: Heinle and Heinle Publishers.

[27] O'Malley, J. M., Chamot, A.U., Stewner-Manzanares, G., Russo, R. P., \& Kupper, L. (1985b). Learning strategy applications with students of English as a second language. TESOL Quarterly, 19, 557-584.

[28] O'Malley, J. M. (1987). The effects of training in the use of learning strategies. In: Nunan, D. (Ed). (1999). Second language teaching and learning. Boston, Massachusetts: Heinle and Heinle Publishers.

[29] O'Malley, J. M., \& Chamot, A.U. (1990). Learning strategies in second language acquisition. In: Cook, V. (Ed). (2001). Second language learning and language teaching. London: Arnold Publishers.

[30] Oxford, R. (1989). Use of language learning strategies: A synthesis of studies with implications for strategy training. System, $17,235-247$.

[31] Oxford, R. (1990). Language learning strategies: What every teacher should know. In: Carter, R. \& Nunan, D. (Ed). (2002). The Cambridge guide to teaching English to speakers of other languages. Cambridge: Cambridge University Press.

[32] Oxford, R. (1994). Language learning strategies: An update. ERIC Identifier, No. ED376707.

[33] Oxford, R., Crookall, D., Cohen, A., Lavine, R., Nyikos, M., \& Sutter, W. (1990). Strategy training for language learners: Six situational case studies and a training model. Foreign Language Annals, 22, 197-216.

[34] Rahmatollahpour, R. (2006). Investigating language learners' strategies: Variations across proficiency levels. Unpublished M.A. thesis. Ahvaz: Islamic Azad University, Science and Research Center.

[35] Richards, J. C. \& Platt, J. (1992). Longman dictionary of language teaching and applied linguistics. Essex: Longman.

[36] Richards, J. C., Hull, J., \& Proctor, S. (2000). New interchange: English for international communication. Cambridge: Cambridge University Press.

[37] Richards, J. C. \& Schmidt, R. (2002). Longman dictionary of language teaching and applied linguistics. Essex: Longman.

[38] Ridley, D.S., Schutz, P.A., Glanz, R.S. \& Weinstein, C.E. (1992). Self-regulated learning: The interactive influence of metacognitive awareness and goal-setting. Journal of Experimental Education, 60 (4), 293-306.

[39] Rost, M. (1990). Listening in language learning. In: Carter, R. \& Nunan, D. (Ed). (2002). The Cambridge guide to teaching English to speakers of other languages. Cambridge: Cambridge University Press. 
[40] Rubin, J. (1975). What the "good language learner" can teach us. TESOL Quarterly, 9, 41-51.

[41] Rubin, J. \& Thompson, I. (1982). How to be a more successful language learner. In: Brown, H. D. (Ed). (1994). Principles of language learning and teaching. New York: Prentice Hall Regents.

[42] Sternberg, R. J. (1984). What should intelligence tests test? Implications for a triarchic theory of intelligence for intelligence testing. Educational Researcher, 13 (1), 5-15.

[43] Sternberg, R. J. (1986). Inside intelligence. American Scientist, 74, 137-143.

[44] Swanson, C. H. (1986). Teachers as listeners: An exploration. The 7th Annual Convention of the International Listening Association.

[45] Takallou, F. (2011).The effect of meta cognitive strategy instruction on EFL reading comprehension performance and meta cognitive awareness. Asian EFL journal Quarterly, 2, 272-300.

[46] Taylor, N. E (1983). Metacognitive ability: A curriculum priority. Reading Psychology: An International Quarterly, 4, $269-278$.

Keramat Ahmadi has an M.A. in TEFL from the Islamic Azad University, Shahreza Branch, Iran. He is already in English Dept. at Payame Noor (PNU) and Islamic Azad University (IAU), Kazeroon, Iran where he has taught courses in EFL, ESP \& has been teaching English since 2011.

Saeed Ketabi has a Ph.D in Applied Linguistics from the University of Cambridge, England and is currently teaching ELT course. He has published and presented several papers and books.

Mitra Rabiee holds a Ph.D. in TEFL from Islamic Azad University, Science \& Research Campus in Iran. She is currently an assistant professor in English Dept. at IAU \& has been teaching English since 1992. She has presented almost twenty papers in National \& International seminars \& conferences and published a couple of articles in different ELT journals. Her major academic interests include SLA issues, ELT methodology, and psycholinguistics. 